\title{
Glycolysis and Lipogenesis in the Livers from Children with Type I of Glycogen Storage Disease
}

By

\author{
Keiya Tada, Tasuke Shibuya and Jinzo Akabane \\ From the Department of Pediatrics, Faculty of Medicine, Tohoku \\ University, Sendai; Director: Prof. Ts. A rakawa \\ (Received for publication, November 1, 1963)
}

\begin{abstract}
The contents of glycogen and fat and the activities of glucose-6-phosphatase (G6Pase), glucose-6-phosphate dehydrogenase (G6PD), glycolysis and lipogenesis were investigated in the livers from three patients with Type I of glycogen storage disease. The contents of glycogen and fat were markedly increased. The activity of G6Pase was definitely low and that of G6PD was normal or slightly increased. The activity of glycolysis was elevated and that of lipogenesis from glucose seemed to be accelerated.
\end{abstract}

In our preceding studies on congenital steatosis of the liver ${ }^{1,2)}$, it was found that there were a decrease in glucose-6-phosphatase (G6Pase) activity, an increase in glucose-6-phosphate dehydrogenase (G6PD) activity and an enhancement in activity of glycolysis and of lipogenesis from glucose in the liver from an infant with congential steatosis of the liver. In conclusion, we presumed that congenital steatosis of the liver had a defect of G6Pase in common with Type I of glycogen storage disease (von Gierke's disease) and that an enhanced lipogenesis from carbohydrate, probably due to increased activity of pentose phosphate pathway, played an important role in the development of fatty liver in congenital steatosis.

It has been known ${ }^{3-7)}$ that considerable amounts of fat often accumulate in the liver of von Gierke's disease. In this respect, the present paper reports the results of our investigations upon activity of glycolysis and of lipogenesis in the livers from three children with von Gierke's disease.

\section{METHODS AND MATERIALS}

Three patients with typical von Gierke's disease were subjected to the present investigation. These three children showed short stature, immense abdominal distension due to massively enlarged liver, a tendency to adiposity and

多田啓也, 浴多助, 赤羽仁三 
occasional episodes of epistaxis. Laboratory examinations revealed a fasting hypoglycemia, a poor response of blood sugar to adrenaline, and striking elevations of blood lactic and pyruvic acids, and of serum total lipids, triglycerides, phospholipids, and cholesterol (cf. Table I). The liver biopsy showed a marked accumulation of fat as well as glycogen (cf. Fig. 1).

Table I. Laboratory Findings of Patients with Type 1 of Glycogen Storage Disease

\begin{tabular}{|c|c|c|c|c|}
\hline & $\begin{array}{c}\text { Case I } \\
\text { A male, } 13 \\
\text { years old }\end{array}$ & $\begin{array}{c}\text { Case II } \\
\text { A female, } 13 \\
\text { years old }\end{array}$ & $\begin{array}{c}\text { Case III } \\
\text { A male, } 10 \\
\text { years old }\end{array}$ & Normal range \\
\hline $\begin{array}{l}\text { Blood } \\
\text { Glucose } \mathrm{mg} / \mathrm{dl} \\
\text { Lactate } \mathrm{mg} / \mathrm{dl} \\
\text { Pyruvate } \mathrm{mg} / \mathrm{dl} \\
\text { Blood glucose re- } \\
\text { sponse to adrenaline }\end{array}$ & $\begin{array}{l}49-66 \\
6.30 \\
\text { poor }\end{array}$ & $\begin{array}{l}53-54 \\
81.0 \\
8.2 \\
\text { poor }\end{array}$ & $\begin{array}{l}45-56 \\
21.2 \\
6.7 \\
\text { poor }\end{array}$ & $\begin{array}{c}70-90 \\
5-20 \\
0.8-1.5\end{array}$ \\
\hline $\begin{array}{ll}\text { Serum } & \\
\text { Total lipids } & \mathrm{mg} / \mathrm{dl} \\
\text { Triglyceride } & \mathrm{mg} / \mathrm{dl} \\
\text { Phospholipids } & \mathrm{mg} / \mathrm{dl} \\
\text { Cholesterol } & \mathrm{mg} / \mathrm{dl} \\
\quad \text { Free } & \mathrm{mg} / \mathrm{dl} \\
\text { Esterified } & \mathrm{mg} / \mathrm{dl}\end{array}$ & $\begin{array}{c}1411 \\
1222-1664 \\
536 \\
243-450 \\
88-205 \\
155-245\end{array}$ & $\begin{array}{c}1320-1375 \\
701-984 \\
353-388 \\
235-320 \\
63-90 \\
144-210\end{array}$ & $\begin{array}{c}1510-2310 \\
592-782 \\
353-733 \\
165-825 \\
51-108 \\
97-774\end{array}$ & $\begin{array}{r}500-700 \\
0-300 \\
200-300 \\
150-200 \\
50-70 \\
100-130\end{array}$ \\
\hline
\end{tabular}

Liver specimens, weighing about $2 \mathrm{~g}$, were removed surgically from these patients. As controls, surgical patients without liver involvement were subjected to liver biopsy. Each of the removed liver specimens was devided into two portions. One portion was homogenized with a chilled isotonic $\mathrm{KCl}$ solution and the other was subjected to make tissue slices. These procedures were quickly carried out at $0^{\circ} \mathrm{C}$.

The homogenates were analyzed according to the following procedures:Nicro-Kjeldahl's method for total nitrogen; Kahn's method ${ }^{8)}$ for glycogen; Smith's method ${ }^{9}$ for total fat; Swanson's method ${ }^{10)}$ for G6Pase; and Glock's method ${ }^{11)}$ for G6PD. Each of liver slices, prepared from the ice-cold liver tissue, was put into incubation flasks of the Warburg manometer under the condition shown in Table II.

The activity of glycolysis in the liver was investigated by manometric determination of lactic acid produced for one hour at $37^{\circ} \mathrm{C}$ under the anaerobic condition.

The activity of lipogenesis from glucose in the liver was investigated by determining isotopically the conversion rate of $\mathrm{C}^{14}$-labeled glucose to fat. The incubation was carried out for three hours at $37^{\circ} \mathrm{C}$ under the aerobic condition. At the end of the incubation, the fat fraction was isolated from the reaction 
Fig. 1. Histological finding of the livers from the patients with Type Ia of lglycogen storage disease.
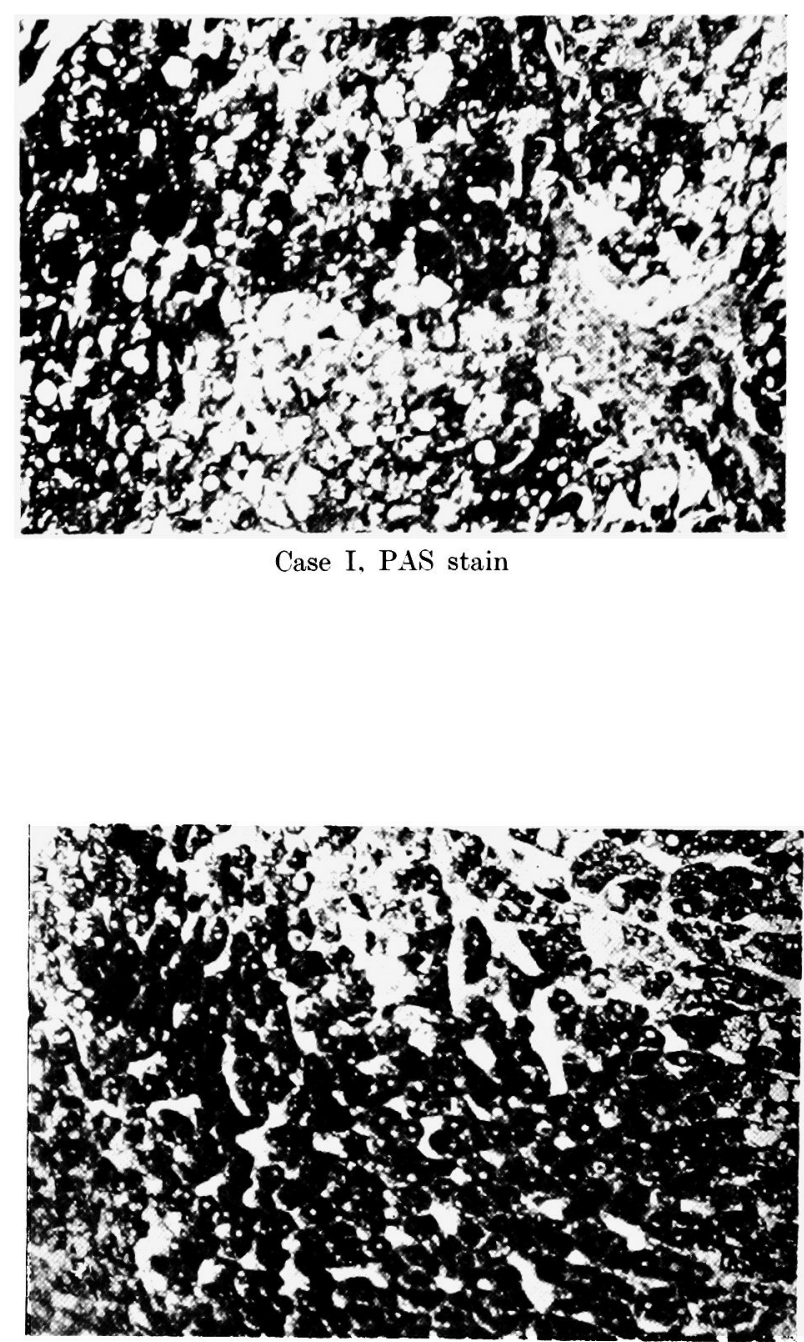

Case II. PAS stain 


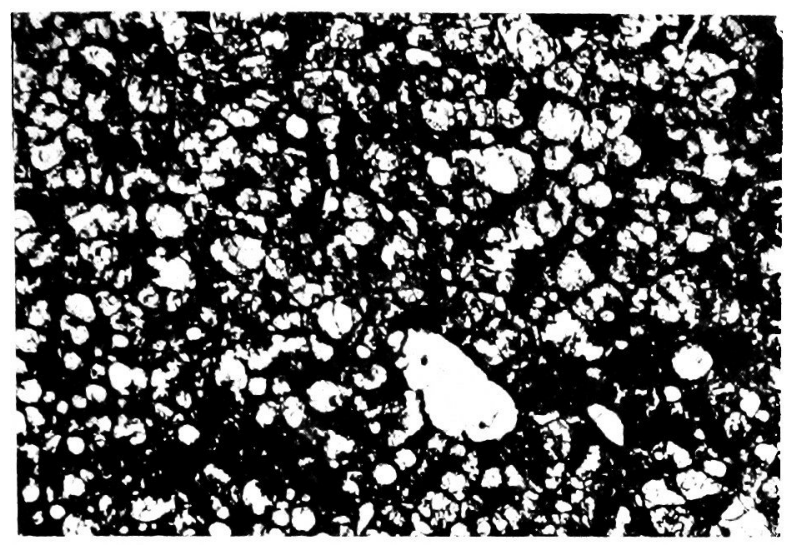

Case III, PAS stain
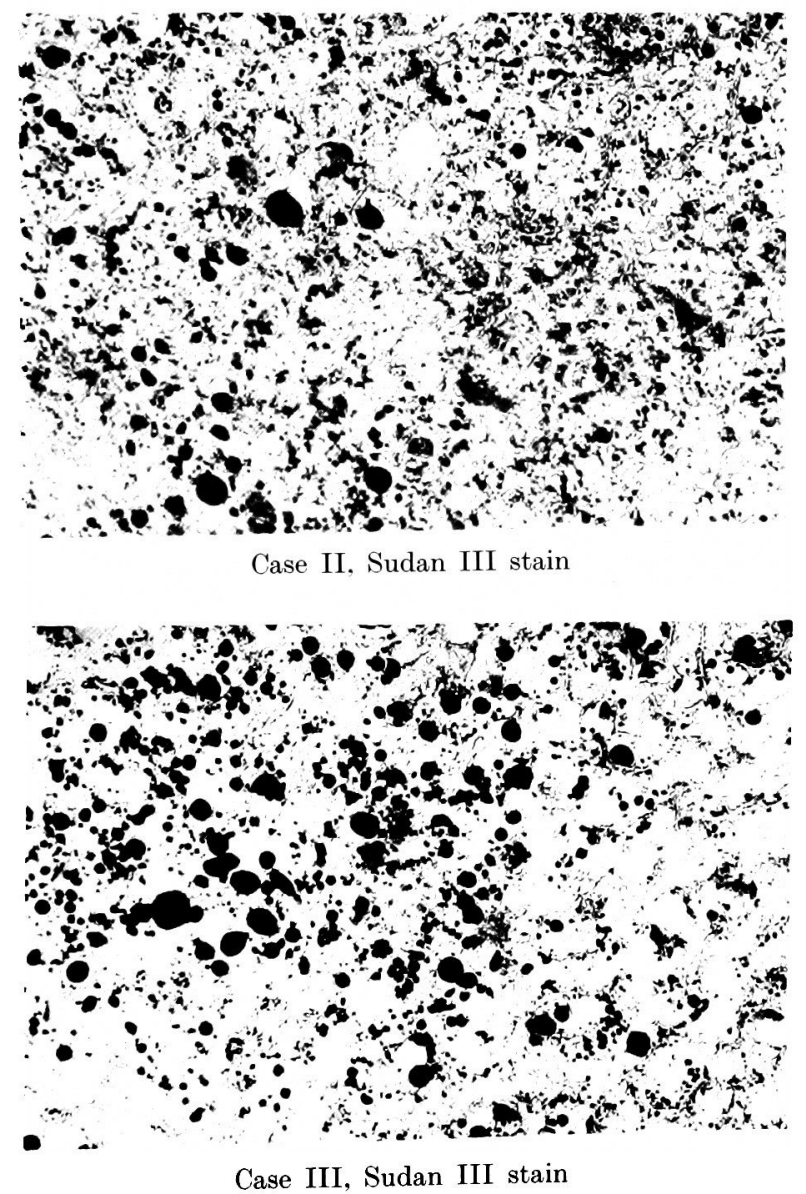
TABLE II. Experimental Conditions for Determination of Activity of Glycolysis and Lipogenesis

\begin{tabular}{l|c|c} 
& Glycolysis & Lipogenesis \\
\hline In cup & K.R.B.* $2.0 \mathrm{ml}$ & K.R.B. 2.0 ml \\
Side & Glucose $0.2 \mathrm{ml}(10 \mathrm{mg})$ & Glucose 0.2ml $(10 \mathrm{mg})$ \\
& & C $^{14}$-Glucose $0.1 \mathrm{ml}(2 \mu \mathrm{c})$ \\
Atmosphere & $95 \% \mathrm{~N}_{2}, 5 \% \mathrm{CO}_{2}$ & Air \\
Time (h.) & 1 & 3 \\
Temperature & $37^{\circ} \mathrm{C}$ & $37^{\circ} \mathrm{C}$
\end{tabular}

* K.R.B.: Krebs-Ringer-bicarbonate solution

mixture by the following method ${ }^{12)}$. The reaction mixture was triturated and dehydrated with anhydrous sodium sulfate and then extracted with hot ethanol. The extracted fraction was completely evaporated to remove ethanol and the fat fraction was isolated from the residue by reextraction with ether. The radioactivity in the fat fraction was counted by gas flow counter with the scaler of Radiation Counter Aloka DC-5.

\section{RESULTS}

Table III showed the results of chemical and enzymatic analyses of the liver from the patients with von Gierke's disease. The contents of glycogen and of fat were remarkably increased in the patients' livers as compared with those in the control livers. G6Pase showed definitely low activities in the patients' livers as compared with that in the control livers. G6PD activity in the liver was normal in Case II and higher in Cases I and III as compared with that in the controls.

Table IV showed the results of in vitro activity of glycolysis in the livers from the patients. The activity of glycolysis was of significantly high level in the liver from the patient of Case I, although unfortunately the results of specimens

TARLE III. Chemical and Enzymatic Analyses of the Lviers from Patients with Type 1 of Glycogen Storage Disease

\begin{tabular}{ll|c|c|c|c}
\hline & Case I & Case II & Case III & Controls \\
\hline Glycogen & $\mathrm{mg} / \mathrm{mgN}$ & 5.71 & 23.7 & 18.5 & $4.0>$ \\
Fat & $\mathrm{mg} / \mathrm{mgN}$ & 4.70 & 8.20 & 20.8 & $1.5>$ \\
G6Pase & $\mathrm{U} / \mathrm{mgN}^{*}$ & 0.042 & 0.05 & 0.07 & $0.2-0.3$ \\
G6PD & $\mathrm{U} / \mathrm{mgN}^{* *}$ & 0.107 & 0.080 & 0.150 & $\left\{\begin{array}{l}0.075 \\
0.085\end{array}\right.$
\end{tabular}

Note: Figures are given as values per $1 \mathrm{mg}$ of nitrogen in the liver.

* The unit of G6Pase activity was expressed as mg of phosphorus liberated from glucose-6-phosphate for 30 minutes at $37^{\circ} \mathrm{C}$.

** The unit of G6PD activity was expressed as the change in optical density per minute per mg of liver nitrogen. 
TABLE IV. Activity of Glycolysis in the Lviers from Patients with Type 1 of Glycogen Storage Disease

\begin{tabular}{c|c|c|c|c}
\hline & Case I & Case II & Case III & Controls \\
\hline Glycolysis & & & & \\
$\mathrm{Q}_{\mathrm{CO}_{2} \mathrm{~N}_{2} \mu l \mathrm{co}_{2} / \mathrm{h} .}$ & 67.0 & Failed* & Failed* & 16.9 \\
& & & & 18.9 \\
& & & & 35.2
\end{tabular}

Note: Figures are given as values per $1 \mathrm{mg}$ of nitrogen in the liver.

* The results could not be obtained by accidental error.

TABLE V. Conversion of $\mathrm{C}^{14}$-Glucose to Fat by the Lviers from Patients with Type 1 of Glycogen Storage Disease

\begin{tabular}{l|c|c|c|c|c}
\hline & $\begin{array}{c}\text { Recovered in } \\
\text { the fat frac- } \\
\text { tion (cpm) }\end{array}$ & $\begin{array}{c}\text { Conversion } \\
\text { rate } \\
(\%)\end{array}$ & $\begin{array}{c}\text { Wet weight } \\
\text { of liver slice } \\
(\mathrm{mg})\end{array}$ & $\begin{array}{c}\text { The content } \\
\text { of nitrogen } \\
\text { in liver slice } \\
(\mathrm{mg})\end{array}$ & $\begin{array}{c}\text { Counts in the fat frac- } \\
\text { tion per 0.1 mg of } \\
\text { nitrogen in liver } \\
\text { slice }\end{array}$ \\
\hline Case I & 7379 & 5.48 & 38 & 0.448 & 1647 \\
Case II & 7601 & 5.63 & 53 & 0.208 & 3654 \\
Case III & 13784 & 10.21 & 35 & 0.128 & 10768 \\
Controls & 8685 & 6.41 & 45 & 0.707 & 1229 \\
& 14087 & 10.42 & 32 & 0.682 & 2066
\end{tabular}

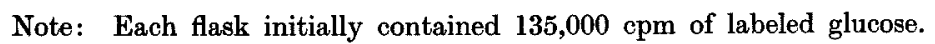

from two other patients could not be obtained by accidental error.

Table $\mathrm{V}$ showed the results of in vitro activity of lipogenesis from glucose in the livers from the patients. There was no remarkable difference in the conversion rate from glucose to fat between the patients' and control livers. However, it should be taken in consideration that the patients' liver contained less nitrogenous component, because of being occupied by excess amounts of glycogen and fat, than the control livers. When counts recovered in the fat fraction were calculated on the basis of unit nitrogen in each of liver slices, a significantly higher counts were obtained in the patients' liver than in the controls. This suggests that the patients' liver may have an enhanced activity of lipogenesis from glucose on protein basis.

\section{DISCUSSION}

In 1960, Weber and Harpur ${ }^{13)}$ reported that both G6Pase and G6PD were lacking in the liver from a patient of glycogen storage disease. Their observation gave rise to a big problem ${ }^{14}$, - an existence of dual enzyme defect in an inborn error of metabolism -, in view of the hypothesis "one gene one enzyme theory" which has been currently accepted. However, this opinion of dual enzyme defect in glycogen storage disease was denied by Howell et al. ${ }^{15}$ ) who 
demonstrated an almost normal activity of G6PD in the liver from a patient with G6Pase deficiency glycogen storage disease. Our present results were in favor of Howell's observation, and indicated a normal or somewhat high level of G6PD activity and a remarkably low level of G6Pase activity in the livers from three patients with von Gierke's disease (cf. Table II). Such a discrepancy respecting G6PD activity by different investigators may be ascribed to the fact that the enzyme G6PD is very unstable in homogenate of human liver ${ }^{15}$.

It has been known ${ }^{16}$ ) that elevations of lactate and pyruvate in blood are frequently seen in patients with von Gierke's disease. Our own patients also showed elevations of lactate and pyruvate in blood (cf. Table I). There are reports ${ }^{15,17)}$ that further elevation of lactate in blood following the administration of glucagon or epinephrine, which does not occur in normal individuals, does occur in patients with this particular disease. In normal individuals, the administration of glucagon or epinephrine results in a sharp rise in blood glucose but in no rise in blood lactate, while it results in an obvious elevation of blood lactate and in a slight rise in blood sugar in patients with von Gierke's disease. This phenomenon is interpreted as follows ${ }^{16)}$. In normal individuals, glycogenolytic agents such as glucagon or epinephrine stimulate breakdown of glycogen and subsequently increase in free glucose in blood. On the other hand, in von Gierke's disease glucose-6-phosphate produced as an intermediate of glycogen breakdown by the agent may be degradated to pyruvate and lactate via Embden-Meyerhof or pentose phosphate pathway, since the liver of the disease is unable to dephosphorylate glucose-6-phosphate and to discharge glucose into blood.

The results obtained in the present studies that the liver from the patient with von Gierke's disease showed an enhanced activity of glycolysis will give us a direct evidence for the assumption mentioned above (cf. Table III).

The conversion of glucose to fat by the livers of this particular disease was found to be accelerated as was evidenced by the present studies (cf. Table IV). This finding is essentially in agreement with that in the patient with congenital steatosis reported by us $^{1,2}$. In our previous papers ${ }^{1,2)}$, it was reported that the liver from a patient with congenital steatosis had a definitely decreased activity of G6Pase, an increased activity of G6PD and an enhanced activity of glycolysis and lipogenesis.

Therefore, the difference in metabolic abnormality between congenital steatosis of the liver and von Gierke's disease may be not qualitative but quantitative. It is conceivable that congenital steatosis of the liver may be an extreme case of type I of glycogen storage disease as regards fat accumulation in the liver.

As was discussed in previous papers as to the development of fatty liver in congenital steatosis ${ }^{1,2}$ ), an enhanced lipogenesis from carbohydrate might play an important role in fat accumulation in the liver of von Gierke's disease.

Although it is difficult to understand why lipogenesis is accelerated in this 
particular disorder, the following assumption may be allowed.

In the first place, the defect of G6Pase which is a primary lesion in this particular disorder may result in excessive production of pyruvate by way of Embden-Meyerhof or pentose phosphate pathway as was mentioned above. The pyruvate, thus produced in excess, may be directed to lipogenesis rather than returning to glycogenesis.

In the second place, the acceleration of lipogenesis might be associated with a probably enhanced activity of the pentose phosphate pathway. According to Siperstein et al..$^{18-20)}$, the incorporation of $\mathrm{C}^{14}$-acetate to fatty acid by liver homogenates of rat was remarkably enhanced when pentose phosphate pathway was stimulated by an addition of TPN into the medium. Howell et al. found that the liver from a patient with G6Pase deficiency glycogen storage disease showed an active operation of the pentose phosphate pathway by investigating the conversion of glucose $1-\mathrm{C}^{14}$ and glucose $6-\mathrm{C}^{14}$ to $\mathrm{C}^{14} \mathrm{O}_{2}$ in an in-vitro experiment. Our own results revealed that G6PD activity in the livers from the patients with von Gierke's disease was normal or somewhat elevated.

It is reasonable to presume that glucose-6-phosphate may be degradated relatively much by way of not only Embden-Meyerhof but also pentose phosphate pathway because of inability of its conversion to free glucose in this particular disorder.

\section{References}

1) Tada, K. et al., Tohoku J. Exper. Med., 1962, 77, 317.

2) Tada, K. et al., Shonika Shinryo (Jap.), 1962, 25, 1123.

3) Harnapp, G.O., Mschr. Kinderheilk., 1936, 66, 194.

4) von Creveld, S., Medicine, 1939, 18, 1.

5) von Creveld, S., Arch. Dis. Child., 1934, 9, 9.

6) Kramer, B. et al., J. Pediat., 1936, 5, 299.

7) Koch, R., Mschr. Kinderheilk., 1954, 102, 9.

8) Kahan, J., Arch. Biochem., 1953, 47, 408.

9) Smith, M.E. \& Kik, M.C., J. biol. Chem., 1933, 103, 391.

10) Swanson, J., ibid., 1950, 184, 647.

11) Glock, G.E. \& McLean, P., Biochem. J., 1953, 55, 400.

12) Hirono, H. \& Ariyama, H., Eiyo to Shokuryo (Jap.), 1961, 14, 212.

13) Weber, G. \& Harpur, E.R., Metabolism, 1960, 9, 880.

14) Anerbach, V.H. \& Digeorge, A.M., Amer. J. Dis. Child., 1961, 102, 578.

15) Howell, R.R. et al., Pediatrics, 1962, 29, 553.

16) Field, R.A., The Metabolic Basis of Inherited Disease, edited by J.B. Stanbury, et al., McGraw-Hill Book Company, 1960, p. 156, New York.

17) Sokal, J.E. et al, Arch. intern. Med., 1962, 109, 158.

18) Siperstein, M.D., Diabetes, 1958, 7, 181.

19) Siperstein, M.D. \& Fagau, V.N., Science, 1957, 126, 1012.

20) Wenner, C.E. et al., J. biol. Chem., 1953, 205, 409. 